\title{
Effect of Drying Methods on Functional and Pasting Properties of Orange Fruit (Citrus sinensis, L.) Peel Flour and Wheat Flour Blends
}

\author{
${ }^{1}$ Rwubatse, Bernard, ${ }^{2}$ Akubor, Peter Issah and ${ }^{3}$ Mugabo, Emmanuel \\ ${ }^{1,2}$ Departement of Food Science and Technology, University of Nigeria,Nsukka, Nigeria \\ ${ }^{3 .}$ Departement of Food Science and Nutrition, University of Ghana, Legon, Ghana
}

\begin{abstract}
Sweet orange fruit peels were dried to constant weight using oven, solar and sun drying methods and then transformed into flour. The orange fruit peel flours from different drying methods were blended with wheat flour in the ratios of 10,20 and $30 \%$. The blends were determined for functional and pasting properties. The water and oil absorption capacities of wheat flour/sun dried orange fruit peel flour blends varied from $180 \%$ to $330 \%$, and $143 \%$ to $150 \%$, respectively and these values were than those of the other blends. The wheat flour/sun dried orange fruit peel flour blends had lower pasting temperature $\left(88.0-88.5^{\circ} \mathrm{C}\right)$ and lower peak time (6 - 6.7 minutes) than those of the other blends. The final viscosity (310.5 RVU) of the $10 \%$ oven dried orange fruit peel flour was the highest. The results showed the flour from orange fruit peels dried by simple and cheap drying methods could supplement wheat flour to improve the functional and pasting properties during food preparation like baking.
\end{abstract}

Keywords: Orange fruit peel flour, Blends, Drying methods, Functional and Pasting properties

\section{Introduction}

Growing population needs for sustainable food security is increasing. Roughly $1 / 3$ of the food production is lost or wasted every year [1]. The $13.5 \%$ people worldwide are undernourished in 2012-2014 years. One billion of people across the world go to bed hungry [2].

Therefore, one of many nutrition-sensitive technological innovations under a changing climate is to reduce and prevent postharvest losses and food waste as it was the theme of Our Common Food Ideas Competition and to search for new food sources as it is in agenda be of the Brazil International Congress on Advances in Food Processing, Challenge for the Future [3,4]. A high percentage of peels is still thrown away after eating or processing orange fruits (Citrus sinensis, L.). The waste of these peels contribute to pollution of the environment. In purpose of reducing this waste, the peels of orange fruits can be processed into flour to supplement wheat flour during preparation of different food products. To prepare blends with wheat flour, the flour of orange fruit peel should have good functional and pasting properties. These properties are intrinsic physicochemical characteristics which affect the behavior of foods during processing, manufacturing, storage, and preparation [4]. The orange fruit peel may be used as a gelling agent, thickening agent and stabilizer in foods due to the high amount of pectin it contains [5]. Flour prepared from orange peels may be also used to increase viscosity, water and oil absorption capacity in food systems. Citrus fruit peels contain carbohydrates, fat and pectin that contribute to good functional properties. Thus, they can be acceptable as a food ingredient in food industries and at home level. However, for food products to be utilized later, they need to be preserved. Several process technologies have been employed on an industrial scale to preserve food products; the major ones are canning, freezing and dehydration. Among these technologies, drying is especially suited for developing countries with poorly established low temperature and thermal processing facilities. It offers a highly effective and practical means of preservation to reduce post-harvest losses and offset the shortages in supply. In direct solar drying called sun drying, the product is heated directly by the sun's rays and moisture is removed by natural circulation of air due to density differences. For solar drying, the moisture is taken away by the air entering into the cabinet from below and escaping through at the top exit. Solar drier reduces losses and contamination from insects, dust and animals. Solar driers protect food from sunlight, better preserving nutrients and color. Sun and solar drying are simple, economic, sustainable and effective methods.

For this reason, in this study, orange fruit peels that were processed into flour to make blends with wheat flour, were dried using these cheap drying methods in a attempt to reduce the waste of the peels. 


\subsection{Materials}

\section{Materials and Methods}

The materials in this study were ripe orange fruit peels and commercial wheat flour. The peels of sweet orange fruits were collected from orange juice processing plant and brought to the Food Science and Technology laboratory, University of Rwanda/College of Agriculture, Animal Sciences and Veterinary Medicine, Rwanda. The peels were cleaned in tap water, divided into three portions and dried to constant weight. One portion was dried in passive box solar drier at $38.5 \pm 8.6{ }^{\circ} \mathrm{C}$ at air flow pressure lower than $1 \mathrm{mPa}$, another portion was dried in the oven at $50 \pm 1{ }^{\circ} \mathrm{C}$ at air flow pressure at lower than $1 \mathrm{mPa}$ and the third portion was sun dried at $16.5 \pm$ $5.5^{\circ} \mathrm{C}$ at wind movement pressure higher than $1 \mathrm{mPa}$. The dried peels were milled in an attrition mill and sieved through $0.2 \mathrm{~mm}$ mesh sieve. The peel flours from different drying methods were blended with wheat flour in the ratios of 10, 20 and $30 \%$. The blends were analyzed for functional and pasting properties.

\subsection{Analytical methods}

2.2.1. Evaluation of functional properties of orange fruit peel flour/wheat flours blends

Water and oil absorption capacities were determined as described by [6]. Least gelation concentration was evaluated as developed by [7]. Foaming capacity and stability and Bulk density were determined as described by [8].

\subsubsection{Determination of pasting characteristics of orange fruit peel flour/wheat flour blends}

The orange fruit peel/ wheat flours blends were determined for pasting characteristics such as peak time, pasting temperature, peak viscosity, final viscosity, trough viscosity, breakdown viscosity and setback viscosity using a Rapid Visco Analyser (RVA) Series 4(Newport Scientific Pvt. Ltd., Australia) as described by [9].

\subsubsection{Experimental design and statistical analysis}

The experiment was $3 \times 3$ factorial design in randomized complete block (RCB). Data were subjected to one way analysis of variance (ANOVA) using SPSS (Statistical Package for the Social Sciences) software, version 20. Means with significant $(\mathrm{p}<0.05)$ differences were separated by the Least Significant Difference (LSD) test outlined by [10].

\subsection{Functional properties of flours}

\section{Results and discussion}

The functional properties of wheat flour and orange fruit peel flour blends are shown in Table 1.

Table 1. The functional properties of wheat flour and orange fruit peel flour blends

\begin{tabular}{|c|c|c|c|c|c|c|c|c|}
\hline $\begin{array}{l}\text { Drying } \\
\text { methods }\end{array}$ & Flours & WF:OPF & $\begin{array}{l}\text { Water } \\
\text { absorption } \\
\text { capacity } \\
(\%)\end{array}$ & $\begin{array}{l}\text { Oil } \\
\text { absorption } \\
\text { capacity } \\
(\%)\end{array}$ & $\begin{array}{l}\text { Least gelation } \\
\text { concentration } \\
(\%, w / v)\end{array}$ & $\begin{array}{l}\text { Bulk density } \\
(\mathrm{g} / \mathrm{ml})\end{array}$ & $\begin{array}{l}\text { Foaming } \\
\text { capacity } \\
(\%)\end{array}$ & $\begin{array}{l}\text { Foam } \\
\text { stability } \\
(\%)\end{array}$ \\
\hline \multirow{6}{*}{ Oven } & \multirow{6}{*}{ WF:ODOFPF } & $100: 0$ & $130^{f} \pm 1.0$ & $136^{i} \pm 3.0$ & $8.0^{\mathrm{a}} \pm 0.0$ & $0.54^{\mathrm{d}} \pm 0.0$ & $12^{\mathrm{a}} \pm 1.0$ & $2^{\mathrm{a}} \pm 1.0$ \\
\hline & & $0: 100$ & $328^{b} \pm 1.0$ & $145^{\mathrm{de}} \pm 1.0$ & $8.0^{\mathrm{a}} \pm 0.0$ & $0.63^{b} \pm 0.1$ & $\mathrm{ND}$ & ND \\
\hline & & $90: 10$ & $149^{\mathrm{ef}} \pm 1.0$ & $138^{\mathrm{hi}} \pm 2.0$ & $8.0^{\mathrm{a}} \pm 2.0$ & $0.34 \mathrm{~g} \pm 0.1$ & $10^{b} \pm 2.0$ & $1.5^{\mathrm{ab}} \pm 0.0$ \\
\hline & & $80: 20$ & $159.6^{\mathrm{de}} \pm 1.5$ & $140^{\mathrm{gh}} \pm 1.0$ & $6.0^{\mathrm{ab}} \pm 0.0$ & $0.46^{f} \pm 0.0$ & $8.5^{b} \pm 2.0$ & $1.5^{\mathrm{ab}} \pm 0.5$ \\
\hline & & $70: 30$ & $180^{d} \pm 0.5$ & $142^{\mathrm{ef}} \pm 2.0$ & $4.0^{b} \pm 2.0$ & $0.57^{c} \pm 0.2$ & $6.0^{c} \pm 0.0$ & $0.7^{b c} \pm 0.2$ \\
\hline & & $100: 0$ & $130^{f} \pm 1.0$ & $136^{\mathrm{i}} \pm 3.0$ & $8.0^{\mathrm{a}} \pm 0.0$ & $0.54^{\mathrm{d}} \pm 0.0$ & $12^{\mathrm{a}} \pm 1.0$ & $2^{\mathrm{a}} \pm 1.0$ \\
\hline \multirow{4}{*}{ Solar } & \multirow{4}{*}{ WF:SOFPF } & $0: 100$ & $434^{a} \pm 0.0$ & $161^{b} \pm 0.0$ & $6.0^{\mathrm{ab}} \pm 2.0$ & $0.78^{\mathrm{a}} \pm 0.0$ & $\mathrm{ND}$ & ND \\
\hline & & $90: 10$ & $171^{\mathrm{de}} \pm 1.0$ & $140^{\mathrm{gh}} \pm 3.0$ & $8.0^{\mathrm{a}} \pm 2.0$ & $0.48^{e} \pm 0.1$ & $10^{b} \pm 0.0$ & $1.5^{\mathrm{ab}} \pm 1.04$ \\
\hline & & $80: 20$ & $186.6^{\mathrm{d}} \pm 3$ & $143^{e f} \pm 1.0$ & $6.0^{\mathrm{ab}} \pm 0.0$ & $0.56^{c} \pm 0.0$ & $8.5^{b} \pm 1.0$ & $1.5^{\mathrm{ab}} \pm 0.0$ \\
\hline & & $70: 30$ & $304^{b} \pm 1.0$ & $146^{\mathrm{d}} \pm 1.0$ & $4.0^{b} \pm 2.0$ & $0.64^{b} \pm 0.2$ & $6.0^{c} \pm 0.0$ & $0.7^{b c} \pm 0.2$ \\
\hline \multirow{5}{*}{ Sun } & \multirow{5}{*}{ WF:SDOFPF } & $100: 0$ & $130^{\mathrm{f}} \pm 1.0$ & $136^{\mathrm{i}} \pm 3.0$ & $8.0^{\mathrm{a}} \pm 0.0$ & $0.54^{\mathrm{d}} \pm 0.0$ & $12^{\mathrm{a}} \pm 1.0$ & $2^{\mathrm{a}} \pm 1.0$ \\
\hline & & $0: 100$ & $444^{\mathrm{a}} \pm 2.0$ & $170^{\mathrm{a}} \pm 1.0$ & $6.0^{\mathrm{ab}} \pm 2.0$ & $0.78^{\mathrm{a}} \pm 0.0$ & ND & ND \\
\hline & & $90: 10$ & $180^{\mathrm{d}} \pm 0.0$ & $143^{e f} \pm 0.0$ & $8.0^{\mathrm{a}} \pm 1.0$ & $0.48^{e} \pm 0.0$ & $10.0^{b} \pm 0.1$ & $1.5^{\mathrm{ab}} \pm 0.0$ \\
\hline & & $80: 20$ & $240^{c} \pm 2.0$ & $147^{\mathrm{dd}} \pm 1.0$ & $6.0^{\mathrm{ab}} \pm 1.0$ & $0.57^{c} \pm 2.0$ & $8.5^{b} \pm 0.0$ & $1.5^{\mathrm{ab}} \pm 0.0$ \\
\hline & & $70: 30$ & $330^{\mathrm{a}} \pm 3.0$ & $150^{c} \pm 2.0$ & $4.0^{b} \pm 1.0$ & $0.63^{b} \pm 2.0$ & $6.0^{c} \pm 0.2$ & $0.7 b^{c} \pm 0.0$ \\
\hline
\end{tabular}

Values are means \pm SD of 3 replications. Means within a row with the same superscript were not significantly (p 
$>0.05)$ different.WF: Wheat flour, OPF: Orange fruit peel flour, ODOFPF: Oven dried orange fruit peel flour, SOFPF: Solar dried orange fruit peel flour, SDOFPF: Sun dried orange fruit peel flour, ND: Not Detected.

The drying methods significantly ( $\mathrm{p}<0.05$ ) affected water absorption capacity, oil absorption capacity, least gelation concentration and bulk density of the orange peel flours. The sun dried peel flour had the highest water absorption capacity of $444 \%$. This was followed by $434 \%$ for the solar dried orange peel flour. While the oven dried peel flour had the lowest water absorption capacity of $328 \%$. The fiber in the orange peel flour might have been responsible for the high water absorption capacity of the flour [11]. The sun dried peel flour had the highest water absorption capacity may be due to high amount of fiber it contained. The oven dried orange peel flour had low water absorption capacity may be due to low amount of fiber, which may have been degraded by the high heat $\left(50 \pm 1{ }^{\circ} \mathrm{C}\right)$ used. The Water absorption capacity of oven dried peel flour was comparable to that obtained in other work for orange peel flour [12]. The capacity of the orange peel flours for absorption of oil ranged between $170 \%$ and $145 \%$. The sun dried peel flour had the highest oil absorption capacity and the oven dried peel flour had the lowest oil absorption capacity. The oil absorption capacity of peel flours may have been contributed by fiber they contained as discussed for water absorption capacity. In addition to fiber content, the solar and sun dried peel flours had higher oil absorption capacity than the oven dried flour probably due to their higher bulk densities. The oil absorption capacity of the oven dried peel flour was in agreement with the value reported for orange peel flour [13].

The bulk densities of the orange fruit peel flour samples ranged between $0.63 \mathrm{~g} / \mathrm{ml}$ and $0.78 \mathrm{~g} / \mathrm{ml}$. The bulk density of sun dried peel flour $(0.78 \mathrm{~g} / \mathrm{ml})$ which was not significantly $(\mathrm{p}>0.05)$ different from that of the solar dried peel flour $(0.78 \mathrm{~g} / \mathrm{ml})$ was higher than that of the oven dried peel flour $(0.63 \mathrm{~g} / \mathrm{ml})$.The bulk density was reported to be inversely associated with porosity [14].The least gelation concentration of the flours ranged between $6 \%$ and $8 \%$. The oven dried peel flour had the highest value while the sun dried peel flour had the lowest value of least gelation concentration. Variations in the least gelation concentration may be attributed to the relative ratios of different constituents such as protein, carbohydrate, fat in the orange fruit peel flours [15]. All the orange fruit peel flour samples lacked foaming capacity and foam stability. This may be due to the negligible amount of protein in orange fruit peel flours. Protein is responsible for foaming capacity and foaming stability as the gas introduced is entrapped in the food matrix [15].

The supplementation of orange fruit peel flours affected the behavior of wheat flour in the blends. The $100 \%$ wheat flour had lower water and oil absorption capacities of $130 \%$ and $136 \%$ respectively, than the wheat flour supplemented with orange peel flour. The water and oil absorption capacities significantly $(p<0.05)$ increased with increase in the level of orange peel flour in the blends. The result of this study suggests that oven, solar and sun dried orange fruit peel flours would be useful in foods such as bakery products which require hydration to improve handling characteristics. The $30 \%$ SOFPF and $30 \%$ SDFPF had higher water and oil absorption capacities, respectively, than the other blends. The high water absorption capacity of the flours may assure product coesiviness [16]. However, high water absorption is not necessarily useful since a material with very high water absorption capacity may imbibe a disproportionate amount of water and would dehydrate other components in the system [16].The low water absorption capacity of the $100 \%$ wheat flour could be attributed to the presence of low amount of hydrophilic constituents [17]. The low oil absorption capacity of wheat flour suggested the low content of apolar amino acids in the flour [18]. The fiber content of wheat flour and the starch of wheat flour which is insoluble almost in cold water, may also have affected the water and oil absorption capacities of wheat flour [19]. The oil absorption capacity of flour is important as it improves the mouth feel and retains the flavor of foods. The oil absorption capacity is useful in sausages and bakery products [20], suggesting that the wheat flour and orange fruit peel flours blends would be useful in this regards.

The least gelation concentration decreased gradually with increase in the level of the orange peel flours in the blends. However, the least gelation concentrations of the blends containing 10, 20 and $30 \%$ orange peel flours were not significantly $(\mathrm{p}>0.05)$ different from that of the $100 \% \mathrm{WF}$. The low least gelation concentration of blends was attributed to the relative ratio of protein, carbohydrates and lipids that made up the flours and the interaction between such components [6]. Flour with low value of least gelation concentration could be a good thickening agent. The oven, solar and sun dried orange fruit peel flours would be useful in food systems such as puddings and snacks which require thickening and gelling. The gel structure of such food systems provides a matrix for retaining moisture, fat and other added ingredients.

The bulk density increased gradually with increase in the level of dried orange peel flour in the blends. The blends containing 10, 20 and $30 \%$ SOFPF, and 10, 20 and $30 \%$ SDOFPF were not significantly ( $p>0.05)$ different in the bulk density. The substance with low bulk density has high porosity and vice versa. The drying techniques may have changed the particle shape and increased the porosity of the flours. Bulk density could be used in determining the packaging requirement of flour as it relates to the load the sample could carry if allowed to rest directly on one another. Bulk density is also related to the mouthfeel and flavor of the food the flour is 
incorporated in [21]. Low bulk density of the flour would be an advantage in the preparation of high nutrient density weaning foods. The foaming capacity of $12 \%$ and foam stability of $2 \%$ for the $100 \%$ wheat flour were greater than those of the orange fruit peel flour blends. The foaming capacity decreased with an increase in the level of the oven, solar and sun dried orange fruit peel flours. This may have been due to low amount of protein in orange fruit peel flours when compared to that of wheat flour. Foaming capacity of a food material varies with the type of protein, solubility and other factors [20]. The foam stability of $100 \%$ wheat flour was not significantly $(\mathrm{p}>0.05)$ different from those of the blends containing $10 \%$ and $20 \%$ orange peels flours. Good foaming capacity is linked with flexible protein molecule that could reduce surface tension while highly ordered globular protein is relatively difficult to surface denaturation [21]. Foams are used to improve texture, consistency and appearance of foods [20].

\subsection{Pasting properties of flours}

The pasting characteristics of orange fruit peel and wheat flour blends is shown in the table 2 .

Table 2. The pasting properties of wheat flour and orange fruit peel flour blends

\begin{tabular}{|c|c|c|c|c|c|c|c|c|c|}
\hline $\begin{array}{l}\text { Drying } \\
\text { methods }\end{array}$ & Flours & WF:OPF & $\begin{array}{l}\text { Pasting } \\
\text { temperature } \\
\left({ }^{\circ} \mathrm{C}\right)\end{array}$ & $\begin{array}{l}\text { Peak time } \\
\text { (Min) }\end{array}$ & $\begin{array}{l}\text { Peak viscosity } \\
\text { (RVU) }\end{array}$ & $\begin{array}{l}\text { Through } \\
\text { viscosity } \\
\text { (RVU) }\end{array}$ & $\begin{array}{l}\text { Breakdown } \\
\text { viscosity } \\
\text { (RVU) }\end{array}$ & $\begin{array}{l}\text { Final viscosity } \\
\text { (RVU) }\end{array}$ & $\begin{array}{l}\text { Setback } \\
\text { viscosity } \\
\text { (RVU) }\end{array}$ \\
\hline \multirow{5}{*}{ Oven } & \multirow{5}{*}{ WF : ODOFPF } & $100: 0$ & $87.8^{c} \pm 0.3$ & $5.5^{c} \pm 0.0$ & $278.3^{\mathrm{s}} \pm 3.1$ & $239.6^{c} \pm 5.1$ & $38.7^{9} \pm 0.9$ & $331.4^{3} \pm 1.2$ & $91.8^{\mathrm{a}} \pm 1.4$ \\
\hline & & $0: 100$ & $92.4^{\mathrm{a}} \pm 1.0$ & $9.5^{3} \pm 0.0$ & $141.8 \mathrm{~g} \pm 1.0$ & $145.2^{f} \pm 0.0$ & $3.4^{\mathrm{f}} \pm 2.0$ & $203.5^{\mathrm{i}} \pm 3.2$ & $58.3^{c} \pm 0.2$ \\
\hline & & $90: 10$ & $89.0 b=0.0$ & $6.5^{b c} \pm 2.9$ & $240.5^{\mathrm{bcd}} \pm 2.0$ & $243.5^{b} \pm 3.0$ & $3.0 f \pm 0.0$ & $310.5^{b} \pm 0.1$ & $70.0^{b} \pm 0.0$ \\
\hline & & $80: 20$ & $90.0^{\mathrm{ab}} \mathrm{c} \pm 3.0$ & $7^{b c} \pm 1.0$ & $210.2^{2 f_{ \pm}} \pm 0.9$ & $215.7^{\mathrm{d}} \pm 5.3$ & $5.5^{\circ} \pm 0.1$ & $240.7^{f_{ \pm}} \pm 0.6$ & $25.0^{\circ} \pm 1.0$ \\
\hline & & $70: 30$ & $91.0^{a b} \pm 1.0$ & $8^{a b} \pm 1.0$ & $201.3^{f} \pm 0.1$ & $205.2 \div 0.0$ & $3.9^{f} \pm 0.7$ & $220.5^{h} \pm 0.1$ & $15.3^{f} \pm 0.1$ \\
\hline \multirow{5}{*}{ Solar } & \multirow{5}{*}{ WF : SOFPF } & $100: 0$ & $87.8 c \pm 0.3$ & $5.5 c \pm 0.0$ & $278.3^{\mathrm{s}} \pm 3.1$ & $239.6 \pm 5.1$ & $38.7^{9} \pm 0.9$ & $331.4^{\mathrm{s}} \pm 1.2$ & $91.8^{\mathrm{a}} \pm 1.4$ \\
\hline & & $0: 100$ & $90.6^{a b c} \pm 0.3$ & $8^{a b} \pm 0.0$ & $215.5^{\mathrm{ef}} \pm 5.2$ & $224.6 c \pm 1.2$ & $9.1^{b c} \pm 0.0$ & $253.3 \div \pm 3.2$ & $28.7 \div \pm 0.2$ \\
\hline & & $90: 10$ & $88.5^{b c} \pm 3.2$ & $6.4^{b c} \pm 1.1$ & $248.5^{\text {abcod }} \pm 0.1$ & $255.5 \pm 4.8$ & $7.0^{\mathrm{d}} \pm 0.5$ & $301.0 \div 0.0$ & $45.5^{\mathrm{d}} \pm 5.4$ \\
\hline & & $80: 20$ & $88.7^{b c} \pm 3.3$ & $6.6^{b c} \pm 0.3$ & $230.5^{\text {cdef }} \pm 0.8$ & $240.3^{b} \pm 5.2$ & $9.8^{b} \pm 1.0$ & $258.3^{\mathrm{d}} \pm 0.1$ & $18.0^{\mathrm{f}} \pm 0.0$ \\
\hline & & $70: 30$ & $89.3^{b} c \pm 0.1$ & $7.2^{b c} \pm 0.1$ & $220.3^{\text {def }} \pm 0.1$ & $228.2^{c} \pm 0.2$ & $7.9^{\mathrm{cd}} \pm 0.0$ & $233.7 \mathrm{~g} \pm 3.2$ & $5.5 \mathrm{~g} \pm 1.8$ \\
\hline \multirow{5}{*}{ Sun } & \multirow{5}{*}{ WF : SDOFPF } & $100: 0$ & $87.8^{b c} \pm 0.3$ & $5.5^{c} \pm 0.0$ & $278.3^{3} \pm 3.1$ & $239.6 c \pm 5.1$ & $38.7^{9} \pm 0.9$ & $331.4^{3} \pm 1.2$ & $91.8^{3} \pm 1.4$ \\
\hline & & $0: 100$ & $89.1^{b c} \pm 2.0$ & $7.5^{b c} \pm 0.2$ & $218.1^{\operatorname{def}_{ \pm}} .0$ & $228.5^{c} \pm 3.1$ & $10.4^{b} \pm 1.0$ & $254.2^{e} \pm 4.1$ & $25.7 \pm 0.2$ \\
\hline & & $90: 10$ & $88.0^{b c} \pm 0.0$ & $6^{b c} \pm 2.0$ & $251.5^{\mathrm{ab}} \pm 1.1$ & $260.5^{\mathrm{a}} \pm 4.7$ & $9.0^{b c} \pm 1.0$ & $308.0^{b} \pm 3.0$ & $47.5^{\mathrm{d}} \pm 2.2$ \\
\hline & & $80: 20$ & $88.0^{b c} \pm 1.0$ & $6.4^{b c} \pm 1.0$ & $235.3 \mathrm{cde} \pm 5.0$ & $245.4^{b} \pm 1.0$ & $10.1^{b} \pm 0.9$ & $261.2^{\mathrm{d}} \pm 1.1$ & $15.8^{f} \pm 5.4$ \\
\hline & & $70: 30$ & $88.5^{b c} \pm 0.2$ & $6.7^{b c} \pm 0.0$ & $225.4^{\text {cdef }} \pm 3.2$ & $234.5^{\mathrm{c}} \pm 3.8$ & $9.1^{b c} \pm 1.0$ & $236.4 \mathrm{~g} \pm 0.2$ & $1.9 \mathrm{~g} \pm 0.4$ \\
\hline
\end{tabular}

Values are means \pm SD of 3 replications. Means within a row with the same superscript were not significantly (p $>0.05)$ different.WF: Wheat flour, OPF: Orange fruit peel flour, ODOFPF: Oven dried orange fruit peel flour, SOFPF: Solar dried orange fruit peel flour, SDOFPF: Sun dried orange fruit peel flour, RVU: Rapid Visco Unit.

The drying methods significantly $(\mathrm{p}<0.05)$ affected the pasting temperature, peak time, peak, through, breakdown, final and setback viscosities of orange fruit peel flours. The oven dried orange peel flour had the highest pasting temperature of $92.4^{\circ} \mathrm{C}$ and peak time of 9.5 minutes. The particle size of oven dried peel flour which was small needed higher temperature and more time for the maximum swelling and coalescence of the flour particles than those of solar and sun dried orange peel flours. The sun dried orange peel flour had the highest values of peak, breakdown and final viscosities due its high water absorption capacity. The pasting properties of wheat flour were significantly $(\mathrm{p}<0.05)$ affected by the incorporation of orange fruit peel flours. The WF/SDOFPF blends had lower pasting temperature which ranged between $88.0{ }^{\circ} \mathrm{C}$ and $88.5{ }^{\circ} \mathrm{C}$, and higher peak time which ranged between 6 minutes and 6.7 minutes than those of the other blends. The low pasting temperature provides indication of the minimum temperature for sample cooking, energy cost involved and other component stability [22]. It is clear from the results that the blends containing $10 \%$ SDOFPF are likely to cook faster and consumed less energy, thereby saving cost and time compared to the other samples because of their lower pasting temperature and lower peak time. The WF/SDOFPF blends had higher peak viscosity $(251.5$ RVU - 225.4 RVU) and higher through viscosity (260.5 RVU - 234.5RVU) than those of the other blends. High peak viscosity correlates well with high swelling power which provides indication of the viscous level to be encountered during mixing [23]. Through viscosity measures the ability of the gel to withstand breakdown during cooling [24]. The break down viscosity values for the orange peel flours were low which varied from 3.4 RVU to 10.4 RVU. The higher the breakdown viscosity, the lower the ability of the flour to withstand heating and shear stress during cooking [24]. The WF/ODOFPF blends had higher setback viscosity which varied from 15.3 RVU to 70.0 RVU than those of the other blends. The small particle size of ODOFPF had high setback viscosity due to less energy required to aggregate upon cooling at $50{ }^{\circ} \mathrm{C}$ than that of big particles size of SOFPF and SDOFPF. The setback viscosity is a range where retrogradation (re-ordering of the starch molecules) occurs. The higher the setback viscosity, the lower the retrogradation of the flour paste during cooling and the lower the staling rate of the product made from the flour [25]. Therefore the paste of $10 \%$ ODOFPF would be preferred for its higher setback viscosity than the other blend formulations. 


\section{Conclusion}

The drying methods affected functional and pasting properties of sweet orange fruit (Citrus sinensis, L.) peel flour/wheat flour blends. The sun dried orange peel flour showed higher water and oil absorption capacities than the other dried orange peel flours. The water and oil absorption capacities increased with increase in the level of orange fruit peel flours in the blends. The oven, solar and sun dried orange fruit peel flours were significantly ( $p$ $<0.05)$ different in functional and pasting properties. The oven dried peel flour had the highest value while the sun dried peel flour had the lowest value of least gelation concentration. The least gelation concentration decreased gradually with increase in the level of the orange peel flours in the blends. However, the least gelation concentrations of the blends containing $10,20 \%$ orange peel flours were not significantly $(\mathrm{p}>0.05)$ different from that of the $30 \%$ orange fruit peel/wheat flour blends. The pasting temperature and peak time were lower, and final viscosity was higher for the sun dried orange peel flour than those of the other orange peel flours. The pasting temperature and peak time increased as the level of orange fruit peel flours increased in the blends while peak, breakdown, final and setback viscosities decreased with increase in orange peel flours in the blends. The wheat flour/oven dried orange peel flour blends had higher setback viscosity than those of the other blends. The incorporation of flour from orange fruit peels dried by oven, solar and sun drying methods in wheat flour blends could be useful in food preparation such as baking where good hydration and viscosity of flour are preferred.

\section{References}

[1]. FAO, Global food losses and food waste extent, causes and prevention. Food and Agriculture Organization of the United Nations (Rome, 2013).

[2]. FAO, The State of Food Insecurity in the World, Strengthening the enabling environment for food security and nutrition, Food and Agriculture Organization of the United Nations (Rome, 2014).

[3]. Our Common Food, Postharvest losses and food waste reduction (Ideas competition Switzeland, 2013).

[4]. Elsevier, Advances in food processing, challenge for the future (International Congress, SaoPaulo, Brazilia, November, 2014).

[5]. J. F. Morton, Orange, in fruits of warm climates (Miami, USA Medial Inc., FL, 1987), 134-142.

[6]. S.K.Sathe and D.K Salunkhe, Functional properties of the great Norhern bean (Phaseolus Vulgaris L).Proteins, emulsions, foaming, viscosity and gelation properties, Journal of Food Science, 46, 1981, 71-81.

[7]. C.V. Coffmann and V.V. Garciaj, V.V, Functional properties and amino acid content of a protein isolate from mung bean flour. International journal of Food Science and Technology,12, 1977, 473-484.

[8]. K.Narayara and R.M.S.Narasinga, Effect of partial hydrolysis on winged bean(Psophcocarus tetragonolobus) flour. Journal of Food Science, 49, 1989, 944-947.

[9]. T. S. Noda, M. Tsuda, S. Mori, C.M. Takigawa, K. Endo and K. Saito, The effect of harvested dates on the starch properties of various potato cultivars, Food Chemistry, 86, 2004,119-125.

[10]. R.G. Steel and J. H. Torrie, Principles and procedure of statistics: A biometrical approach ( $2^{\text {nd }}$ edn. Mc-Graw-Hill Publisher, New York, 1980) 34-44

[11]. C.F.Chou and Y.L. Huang,Y. L. (2003). Comparison of the chemical composition and physical properties of different fiber prepared from the peel of orange fruit (Citrus sinensis L.), Journal of Agriculture and Food Chemistry, 51, $2003,2615$.

[12]. J.A.Larrauri, J.L Rodriguez, M.Fernandez and B.Borroto, Note. Dietary fiber obtained from citrus husk and pine- apple peel, Revista Espanola de Ciencia y Tecnologia de Alimentos 34, 1994, 102-107.

[13]. N. Grigelmo-Miguel and O.Martin-Belloso, Comparison of dietary fibre from by-products of processing fruits and greens and from cereals, LWT, 32, 1999, 503-508.

[14]. V. Singh, S.K.Singh and S.Maurya, 2010, Microwave induced poly (acrylic acid) modification of cassia javanica seed gum for efficient $\mathrm{Hg}$ (II) removal from solution, Chemical Engineering Journal , 160, 2010, 129-137.

[15]. I.A.Adeyemi, and S. Umar, Effect of method of manufacture on quality characteristics of kunun zaki, a millet based beverage. Nigeria Food Journal, 12, 1994, 944-947

[16]. P. Houson and G.S. Ayenor, Appropriate processing and food functional properties of maze flour, African Journal of Science and Technology, 3, 2002, 121-126.

[17]. P.I.Akubor and G.I.O. Badifu, Chemicalcomposition, functional properties and baking potential of African bread fruit kernel and wheat flour blends, International Journal of Food Science and Technology 39, 2001 223-229.

[18]. H.Taira, Buckwheat introduction, Encyclopedia of Food Technology (Westport: AVI ,1974)139.

[19]. J.N.Enwere, Foods of plant origin (Afro. orbis Publ. Nsukka, Nigeria,1998) 64-124

[20]. P.I.Akubor and J.I.Eze, Quality evaluation and cake making potential of sun and oven dried carrot fruit, International Journal of Biosciences, 2 (10) 2012, 19 -27.

[21]. I. A. Onimawo and P. I. Akubor, Food chemistry. Integrated approach with biochemical background (Ibadan, Nigeria, Joytal printing press, 2012) 287-290.

[22]. O. J. Ikegwu, V. N. Nwobasi, M. O. Odoh and N. U. Oledinma (2009) Evaluation of the pasting and some functional properties of starch isolated from some improved cassava varieties in Nigeria, African Journal of Biotechnology, 8 (10), 2009, $2310-2315$.

[23]. A. A. Adebowale, M.T. Adegoke, S. A. Sanni, M.O. Adegunwa and G. O. Fetuga, Functional properties and biscuit making potentials of sorghum-wheat flour composite, American Journal of Food Technology, 7, 2012,372-379.

[24]. A. A. Adebowale, L. O. Sanni and S. O. Awonarin, Effect of texture modification on the physicochemical and sensory properties of dried fufu, Food Science and Technology International, 11, 2005, 373-385.

[25]. I. A. Adeyemi and M. A. Idowu, The evaluation of pregelatinized maize flour in the development of Maissa, a baked product, Nigerian Food Journal, 8,1990, 63-73. 